\title{
炭素微粉の高速液体クロマトグラフィー用 カラム充填剤への応用
}

鳥谷部真実・横野哲朗・真田雄三

(平成 2 年 3 月 28 日受理)

\section{Applications of Carbon Powder in Column Packing for High Performance Liquid Chromatography}

Masami Toriyabe, Tetsuro Yokono and Yuzo Sanada

Performance of carbon packed columns for HPLC was tested. Carbons were prepared from PAN, nitrated and sulfonated coal tar pitches over the temperature range $600 \sim 900^{\circ} \mathrm{C}$. D-glucose, sucrose and raffinose dissolved in distilled water were selected as moving phase.

The highest performance of separation was obtained with the carbons baked at $800^{\circ} \mathrm{C}$.

EKYWORDS: Column Packing, High performance liquid chromatography, D-glucose, Sucrose, Raffinose, Carbon powder

\section{1. 緒言}

著者らは $n$-パラフィンからの炭素小球体扔よび炭素 微粉を高速液体クロマトグラフィー用カラム充填剂に用 いた場合, 種々の多環芳香族, および芳香族酸性物質や

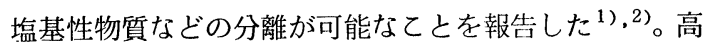
速液体クロマトグラフィー（HPLC）の急速な進歩の要 因となったのは様々な生体関連物質の分離法への可能性 が高いからであるといわ机いる。本報告では HPLCの 応用を計るうえで水溶性物質である糖類の分離について 検討を行なった結果を述べたものである。市販されてい る糖類分離用力ラムの中には, アミノ基等で修飾された あのが知られている3 ${ }^{3)}$ (4) ととから，乙てではポリアクリ ロニトリル (PAN) を主成分とする共重合体 Polymer$\mathrm{A}$ を充填剤の出発原料として用いた。また, 糖類, 糖了 ルコール類の混合物に対してはスチレンージビニルベン ゼン系共重合体にスルホン基を導入し，その対イオンを $\mathrm{Na}^{+}$などの無機イオンにて交換した粒子をカラム充填剤 として用いる方法も知られている ${ }^{5)}$ 。そてでピッチを硝 酸または硫酸で処理した pitch-A, pitch-Bについてあ 出発原料とし, 乙れら出発原料を所定温度で焼成, 炭化

北海道大学工学部, 金属化学研究施設 炭素系素材部門 : $\mathbf{T} 060$ 札棍市北区北 13 条西 8 丁目
してえられる炭素微粉を充填剂とし, カラム性能の試験 を行なった。

\section{2. 実験}

\section{1 充填剂の製作}

充填剂としては, Polymer-A (PAN90\%からなる高 分子共重合体), pitch-A (石炭系ピッチをニトロ化した あの), pitch-B (石炭系ピッチをスルホン化したすの), A 240 (石油系ピッチ) を原料として次の条件で熱処理し， 微粉炭化物を得た。

1) Polymer-A

原料であるPolymer-A を減圧乾燥器で充分乾燥させ た後, 横型赤外線イメージ炉で H.T.T.600, 700, 750, $800,850,900^{\circ} \mathrm{C}\left(20^{\circ} \mathrm{C} /\right.$ 分, 30 分間保持 $)$, 窒素雾囲気下 で熱処理して炭化物を得た。てれらを乳鉢で粉研し, 200 メッシュ以下 $(<74 \mu \mathrm{m})$ の微粉炭化物を調製した。

2) ピッチ

石炭系ピッチ： pitch-A，pitch-B 扰よび石油系ピッ チ：A 240 を $800^{\circ} \mathrm{C}$ で 30 分間熱処理して得られたコーク スを, 200 メッシュ以下に粉砕したものあ充填剤として 用いた。

てれらの充填戍をステンレス製 HPLC 用カラム ( 4 $\mathrm{mm} \phi, 250 \mathrm{~mm}$ ) に乾式充填法で充填した。 


\section{2 高速液体クロマトグラフィーによる分離測定}

HPLC は RI 検出器を装着したエルマ社製のあのを用 いた。試料水溶液の濃度は $(\sim 1 \mathrm{wt} \%)$ で使用した。乙 の試料溶液 $15 \mu 1$ をカラムに注入した。移動相は純水を 用いた。

\section{3 比表面積の測定}

表面測定装置 湯浅アイオニクス社製オートソープ 1 型 で BET 法（77Kに拀ける窒素ガス吸着法）により求め た。

\section{4 水素受容能力（Aa）の測定}

炭化物表面のキャラクタリゼーションとして水素受容 能力を求めた。水素受容能の評価はガラス管中で炭化物 と水素供与剤である 9, 10 dihydroanthracene (DHA) を $400{ }^{\circ} \mathrm{C}, 5$ 分間, 反応させた後, $\mathrm{CDCl}_{3}$ に溶解し, ${ }^{1} \mathrm{H}$ NMR 測定を行い DHA より炭素表面に移動した水素量 を既知の濃度のアセナフテンと比較して定量した ${ }^{6)}$ 。

\section{$2.5 \mathrm{pH}$ の測定}

試料 $1 \mathrm{~g}$ を蒸留水 $100 \mathrm{ml}$ 中に加えて 15 分間煮沸し, 48 時間放置した後, 炭素懸濁液の水素イオン濃度を $\mathrm{pH}$ メ ーターで測定した。

\section{6 比重の測定}

比重の測定はピクノメーターを用いて測定した。

\section{3. 結果および考察}

\subsection{Polymer-A より生成した微粉炭化物を充填 剂とした場合の分離性能}

Fig. 1 に Polymer-A $600 \sim 900^{\circ} \mathrm{C}$ で熱処理して作 成したカラムを用いた場合の糖類の分離結果を示す。 Polymer-A 600, 700, 750 を用いた時の, 3 種類の糖(Dglucose : 単糖類, sucrose : 二糖類, raffinose : 三糖
類）の分離は, Polymer-A 700, 750 亿 raffinoseによ る肩が若干見える程度で全体的には保持時間がほぼ一致 しこれらの試料を分離することは出来なかった。Polymer-A 800 を用いた場合は明確に 3 本のピークに分離で きた。Polymer-A 850, 900 の場合，前者は D-glucose と sucrose のピークが重なり, 後者は sucrose と raffinose が重なったピークとして検出され, 結局, 三種類 に分離できなかった。

Polymer-A では, $800^{\circ} \mathrm{C}$ で熱処理した炭化物を用い た場合，分離能が最む優れているととが明らかとなった。

\section{2 各種ピッチより生成した微粉炭化物を充填} 剂とした場合の分離性能

pitch-A, pitch-B，A 240 の熱処理は Polymer-Aで 良好な分離能を示した焼成温度と同様に $800^{\circ} \mathrm{C}$ で行なっ た。Fig. 2 亿 pitch-A 800, pitch-B 800, A 240 800炭 化物を用いた場合の D-glucose, sucrose,ならびに raffinose の分離結果を示す。Fig. 2 より pitch-A 800 を用 いた場合には 3 番目の raffinose のピークが裾広がりな ピークとなったが満足できる分離能を示した。 pitch-B 800 の場合には raffinose を検出することはできなかっ たが, D-glucose と sucrose の差が大きく，ての 2 種 類に関しては明確に分類された。

一方, A 240800 では 3 種類の糖類の保持時間が等し く分離不可能であった。

\section{3 各充填剤の特性}

Table 1 亿各種炭化物の水素受容能力 ( $\mathrm{Aa}), \mathrm{pH}$, 比 重の值を示す。こてで示した充填剤は液相炭化を経てき

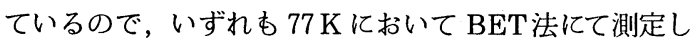
た比重面積は $1 \mathrm{~m}^{2} / \mathrm{g}$ 以下と小さい。また, 他の特性値 ( $\mathrm{Aa}, \mathrm{pH}$, 比重) は熱処理温度 $800^{\circ} \mathrm{C}$ で生成した炭化物

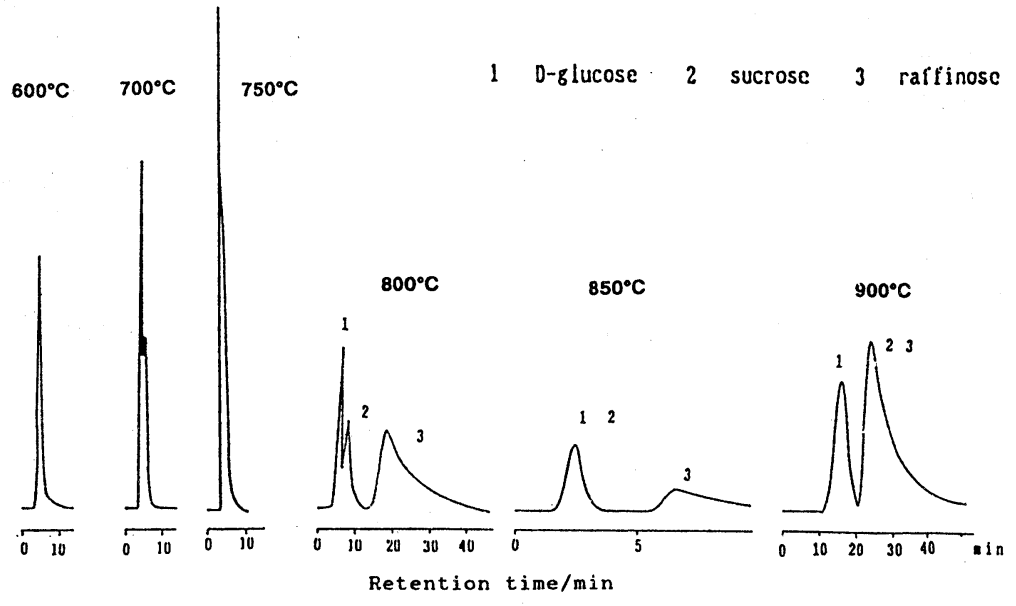

Fig. 1 Separation of sugars by HPLC using carbon powder from. polymer $A$ at various temperatures of heat treatment. 
1 - - -glucose 2 sucrose 3 raftinose

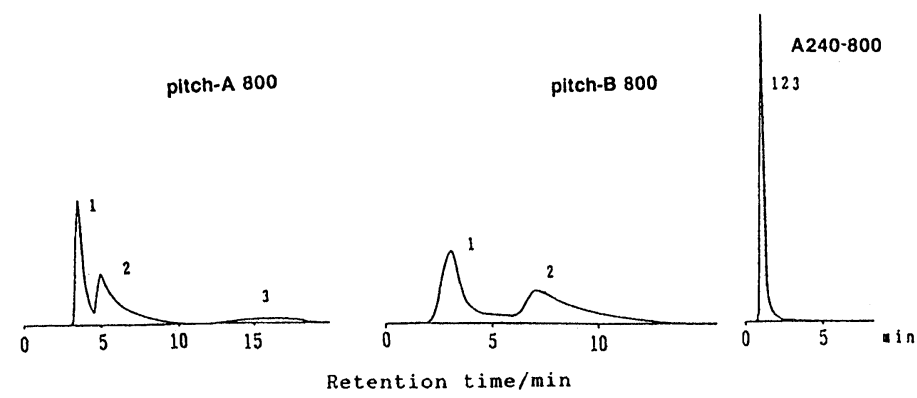

Fig. 2 A comparison of column performance in HPLC of various carbon powders.

Table 1 Properties of carbon column.

\begin{tabular}{ccccc}
\hline Sample & $\begin{array}{c}\text { H.T.T. hydrogen acceptor ability (Aa) } \\
\left({ }^{\circ} \mathrm{C}\right)\end{array}$ & $\begin{array}{c}\mathrm{pH} \\
\left(\mathrm{mg}-\mathrm{H}_{2} / \mathrm{g} \text {-coke }\right)\end{array}$ & $\begin{array}{c}\text { density } \\
\left(\mathrm{g} / \mathrm{cm}^{3}\right)\end{array}$ \\
\hline Polymer-A & 600 & 2.55 & 6.84 & 1.407 \\
& 700 & 2.31 & 6.44 & 1.509 \\
& 800 & 2.06 & 6.64 & 1.593 \\
& 900 & 1.99 & 6.65 & 1.607 \\
pitch-A & 800 & - & - & 1.404 \\
A240 & 800 & - & - & - \\
\hline
\end{tabular}

が特異的とはなっていない。さらに 3 種類の糖の溶出順 序が分子サイズの小さい順に検出され, 平均細孔半径が 約 $12 \AA^{*}$ で市販品のそれと比較するとかなり小さいとと から，サイズ排除を分離機構とするカラム充填剤とは異 なることが考えられる。また, 移動相の極性をメ夕ノ一 ルを加え, 変化させることにより, 糖類に対する保持時 間が短くなることが別のシリーズの実験から明らかとな った ${ }^{7)}$ 。つまり, 充填剂と糖類の相互作用がメタノールの 存在によって大きく影響を受けたためと考えられるので， 炭素表面之糖質の親和性の相違が分離能に関係している と推定される。

以上述べたことより考えられる分離機構を Fig. 3 亿示 した。このモデルでは糖類は水に介して, 充填剤と水素 結合等の相互作用をしており，その相互作用の強弱によ って分離が行なわれる機構である。しかし, 詳細は明ら かでない。また, 糖類の分離には炭化物の光学的異方性 組織とは直接関係は認められなかった。

\section{4 カラムの分離能の評価}

カラムの分離効率を表わすのに理論段数という概念が

*市販されている分子ふるいクロマトグラフィー用充填

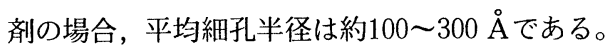

\section{D-glucose}

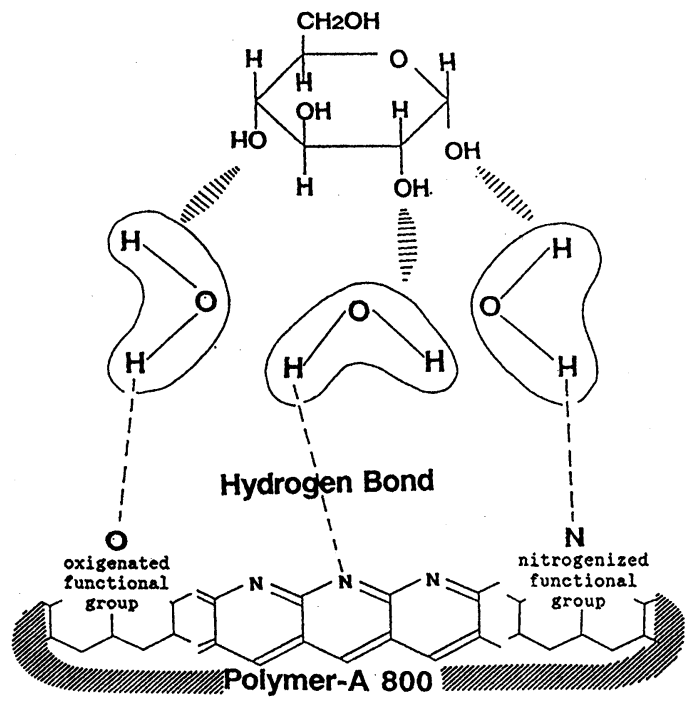

Fig. 3 Suggested model of separation mechanism. 


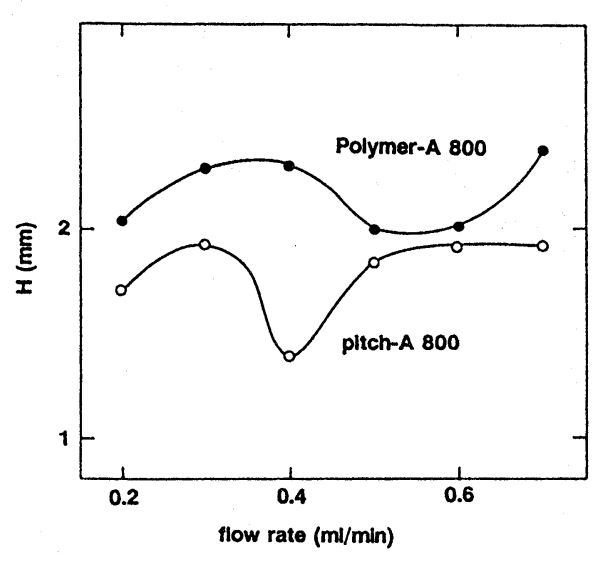

Fig. 4 Height equivalent of a theoretical plate vs. flow rate of eluent.

導入されている。カラム内の分離帯を微小なプレートの 集まりであると想定し，乙の理論段数を分離に必要な平 衡の繰り返しとして考えると, その繰り返される平衡の 理論段数が多いほど分離は良くなる。すなわち，段が多 いほど効率がよいと考える。インジェクト開始時からピ 一クの最大の点までの保持時間を $\mathrm{t}_{\mathrm{R}}$, ピークのバンド幅 を $\mathrm{t}_{\mathrm{W}}$ とすると, 理論段数 $\mathrm{N}$ は

$$
\mathrm{N}=16\left(\frac{\mathrm{t}_{\mathrm{R}}}{\mathrm{t}_{\mathrm{W}}}\right)^{2}
$$

で表わされる ${ }^{8)}$ 。

理論段数 N はカラムの長さLに比例する。乙の比例定 数 1 / H の逆数 Hを一理論段相当高さ (HETP, カラム 効率）といい, カラムの単位長さあたりの効率を表わす。

$$
\mathrm{H}=\frac{\mathrm{L}}{\mathrm{N}}
$$

したがって, Hの小さいカラムは効率の良いカラムであ り，Nの小さいカラムは効率の悪いカラムを意味する。

ここでは著者らが作成した熱处理温度 $800^{\circ} \mathrm{C}$ の Polymer-A 800, pitch-A 800 を対象に理論段数 Nと力ラム 効率 $\mathrm{H}$ を求めてみた。測定は, まず各力ラムで武料成分
D-glucose のみインジェクトし, 流速を $0.2 \sim 0.7 \mathrm{ml} /$ min まで変化させたクロマトグラフを得る。そのクロマ トグラフから保持時間 $t_{\mathrm{R}}$, ピーク幅 $\mathrm{t}_{\mathrm{w}}$ を読み取る。そ れらの値とカラムの長さ $250 \mathrm{~mm}$ とから式 $(1,2)$ より 理論段数 $\mathrm{N}$ とカラム効率 $\mathrm{H}$ を求める。

Fig. 4 亿その結果を示す。Polymer-A 800 は流速 0.5 〜 $0.6 \mathrm{ml} / \mathrm{min}$ に極小値をむっている。乙れは著者らが 主として行なっていた実験条件に一致している。 pitchA 800 は $0.4 \mathrm{ml} / \mathrm{min}$ に極小值をむっており，その時の カラム効率は他の流速の場合より小さくなった。すなわ ち最も効率の良い流速は $0.4 \mathrm{ml} / \mathrm{min}$ であった。両力ラ

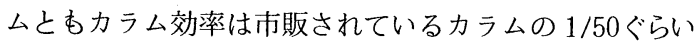
であり，今後改良をしていく必要があろう。

今後は $800^{\circ} \mathrm{C}$ 付近の炭素の物理化学構造の解明之分離 能の相関および分離機構に関する研究が課題であろう。

炭素化物は特有の耐熱性, 耐薬品性を備えているので 種々の移動相のもとで膨張も収縮も少ないクロマトグラ フィー用充填剤として発展する可能性があろう。

\section{文献}

1) T. Yokono, M. Nakahara, K. Makino and Y. Sanada, J. Material Sci. Lett. 7, 894 (1988)

2) 横野哲朗, 中原昌彦, 真田雄三, 炭素 1988 [No. 134] 188

3) F.M. Rabel, A.G. Caputo and E.T. Butts, J. Chromatogr 73, 126 (1976)

4) N.Y. Kim and L.S. Wolfe, Anal. Biochem. 102, 213 (1980)

5) 日本分析化学会関東支部編 “高速液体クロマトグラ フィーハンドブック” p. 99 丸善 (1985)

6) S. Iyama, T. Yokono and Y. Sanada, Carbon 24, 423 (1986)

7) 鳥谷部真実, 横野哲朗, 真田雄三, 未発表

8) L.R. Snyder and J.J. Kirkl and 著,小島次雄, 春木達郎訳 東京化学同人 高速液体クロマトグラ フィー p. 22 